\title{
Niche-Market Tour Operators and Mass-Market On-Line Travel Agencies: The Case-Study of U.S. Organized Tourism to Italy
}

\author{
Oricchio Romina, Testa Silvia, and Nicolò Costa \\ State University Rome Tor Vergata, Italy
}

\begin{abstract}
The design of tourism products is changing due to factors such as the growing importance of the Internet and the ability of tourists to be involved in the production of their own products/experiences, (namely the emergence of the 'prosumer'). This paper reports a study into the responses of Tour Operators and On-line Travel Agencies to the evolution of the tourism sector. The case-study analyzes the use of marketing mix variables for outbound tourists from the United States booking tours to Italy. A comparison between operators and the five main on-line travel agencies is then made. The purpose of the paper is to demonstrate an ongoing repositioning of these tourism players along the long-tail theory curve and a reversal of the Tour Operator's role, from that of a general mass market orientation to the supply of a niche market demand by promoting customized travel packages based on specific requirements. Implications of this process for the marketing of destinations and SMEs are discussed in the final part of the paper.
\end{abstract}

Keywords: Tour operator, on-line travel agency, web marketing, long tail theory, niche market, mass market, prosumer

\section{Introduction}

The tourism business is continuously evolving. This industry has undergone profound changes from the 1970 s to the present, which are forcing suppliers to renew their products in order to satisfy the emerging demand target requirements and to remain competitive in the global market (Weber \& Roehl, 1999; Beldona, 2005; Buhalis \& O’Connor, 2005; Chabot, 2007; O’Connor, Höpken \& Gretzel, 2008; Egger \& Buhalis, 2008; Au, 2010; Buhalis \& Jun, 2011; Corigliano \& Baggio, 2011). These changes have been favored by the diffusion of digital media and information communication technology (ICT), the Internet Revolution as a new narrow-casting communication means, and the application of all these tools to the Travel \& Leisure tourism market (Buhalis, 1998; Buhalis \& Licata, 2002; Law et al., 2004; Andreau et al., 2010). Buhalis \& Law have provided an overview of the tourism evolution in the last 30 years: from the Computer Reservation System (CRS) in the 1970s to the Global Distribution System (GDS) in the 1980s, to the Internet Revolution in the second half of the 1990s (Buhalis \& Law, 2008; Law et al., 2009; Poon, 1988).

The aim of the survey is to understand how TOs are adapting their web marketing strategies in response to ICT development in order to promote and sell their travel destination.
Prior studies (Inkpen, 1998; Law, 2000; Buhalis 1998; Barnet \& Standing, 2001) have focused on the opportunity or threatens for tourist suppliers due to the Internet development. Some others declare that on-line travel services have become one of the largest e-commerce domains around the world (Zhang, 2004; Smith \& Jenner, 1998; Clemons et al, 2002; Buhalis, 2000).

Few studies have analyzed the relationship between TOs and Internet as a new distribution channel (Rachman \& Richins, 1997; Gartner \& Bachri, 1994; Wan, 2002; Cai et al., 2004; Law et al., 2001), rather researchers are often interested to the strong TOs' bargaining power on accommodation companies (Buhalis, 2000; Cavelek, 2000; MedinaMuñoz \& Garcìa-Falcòn, 2000; Karamustafa, 2000; Aguilò et al., 2001; Medina-Muñoz et al. 2001; Bastakis et al., 2002) or to their role as a vehicle of a travel destination image (Baloglu \& Mangaloglu, 1999; Novelli \& Hellwing, 2011; Klemm \& Parkinson, 2001; Trunfio et al., 2006). The Internet revolution is moving the researchers' interests to its impact on travel agencies and consumers behavior and no studies have addressed about the TOs role as new Internet brokers.

Inside the traditional tourism industry, TOs have always played a very important and exclusive role both with destinations and with local tourist services suppliers. Their bargaining power allowed them to 
put together several tourist services in travel packages which were sold to mass market tourism demand (Yale, 1995). With the Internet Revolution and the born of new tourist brokers, like OTAs (Carroll \& Siguaw, 2003; Christodoulidou et al., 2010; Vinoid, 2011), TOs are forced to replace and resize their role inside the tourism industry.

In the attempt to demonstrate those changes, the survey considers the U.S tourism market case-study in terms of the supply and demand toward Italy. The European Tourism Council Study (ETC, 2010) demonstrates that in U.S. tourism market the use of Internet for travel reasons increased more than 50\% since 2000 to 2010 and, in 2010 more than $66 \%$ of U.S. population books a travel on-line. Starting from this data, this survey goes into this trend. A new kind of tourist consumer is emerging: the prosumer (Toffler, 1981) who can be compared to the US online tourist one. After that, the paper collects and analyzes data about two kind of tourist stakeholders: small sized TOs and big OTAs. The firsts have always belonged to the tourism industry chain. Their main duty is to put together the basic services required for a travel enjoyment (i.e. flight + hotel) and then, once the package is ready, a travel agency will going to promote and sell it. The on-line travel agencies, instead, were born thanks to the Internet Revolution, when the four main GDS became websites, covering a new role like e-intermediaries (Buhalis, 2004; Buhalis \& Law, 2008). Step by step OTAs have started to contact the tourism providers services, bypassing the TOs' figure and its role.

The choice to analyze this two tourism players is due to the tourist demand behavior. In fact, the both are examined by the U.S on-line tourist demand during the travel information searching phase (U.S.Travel Association and NLTeC, 2009; PhoCusWright's, 2010; Pan \& Fesenmaier, 2006; Xiang \& Pan, 2011). Because of this phenomenon our hypotheses are:

1. understanding if small-sized TOs are threatened by OTAs;

2. the way TOs react to the advance of OTAs, as a new tourist player;

3. TOs and OTAs place along the tourism chain industry.

To satisfy our hypothesis, a comparison between the two stakeholders is made, referring to the US tourism market to Italy. The survey records the response of TOs and OTAs, referring both to the long tail theory (Anderson, 2006) and to the new consumer behavior due to Internet developments. This is demonstrated by analysis of web marketing tools used by a panel of 11 small-sized U.S. TOs, and the strategy changes in terms of product, price and web promotion. After the
TOs analysis, a comparison with OTAs was made referring to offered destination. We are going to demonstrate how TOs and OTAs are reversing their management strategies in the attempt to catch different tourist target demand, with a consequent their repositioning along the long tail theory curve (Anderson, 2006). To this purpose, we raised the following questions:

1. What place do OTAs and TOs hold in the long tail theory curve?

2. Can new business trends create niche market TOs and mass market OTAs?

3. How do TOs and OTAs react to the tourism demand changes?

4. Thanks to the Internet and web marketing instruments, is the emergence of a new kind of TO, different from the mass-market traditional ones, possible?

\section{Research Background: Prosumerism and Long Tail Theory}

New technological tools have changed the tourism demand, in terms of both life-style and product enjoyment. Internet development is allowing everybody to interact, comment, publish and create contents (Karakas, 2009). According to Granovetter, this new kind of communication creates a network based on the "strength of weak ties" (Granovetter, 1983; Granovetter, 2005; Granovetter \& Swedberg, 2011; Costa \& Testa, 2012). This has given rise to what Tim O'Reilly calls "Web 2.0" (O’Reilly, 2005), defined as the transformation of the Internet into social networks by which to share data, information, services and common passions. Communities with different interests meet around a large number of sites, ready to create a common intelligence able to produce services (prosumerism), information and products (Grassini, 1999).

In this way, the Internet has become an important information tool not only for tourists, but it is also a commercial distribution and sales promotion instrument. Hence, the Internet allows both the business to consumer (B2C) relationship and the development of new market trends.

The Internet is the tourism providers' response to the tourists' new purchase-consumption behavior aimed at satisfying the prosumers' requirements (Milani et al., 2011; Baggio \& Corigliano, 2006).

The prosumer is the new Internet user. According to Toffler (Toffler, 1981), the excessive mass production led to the market saturation. This phenomenon encouraged some changes in B2C relationship. The passive consumer gives way to a 
more participatory one who becomes part of the production process. It means customized services and goods as consumer requires. The web 2.0 and the new digital technologies are increasing the cooperation between consumers and producers favoring the prosumer's birth: an active consumer and producer in the same time (Toffler, 1981; Rifkin, 2000; Choi et al., 2007).

With the birth of the prosumer, the "digital society" becomes the place of individual differences that interact with each other and that constantly claim their individuality (Granieri, 2006). We are facing the so called "mass customization"(Bandulet \& Morasch, 2003), which is the result of shared creativity. The co-creativity (Costa, 2005) combines the individual creativity (customization) with the social creativity (word of mouth, the user generated content and sharing of experiences). It is a shared collective knowledge that allows tourists to make purchase decisions, reasoned and relevant to their needs, with the ability to access the experiences of other tourists that have the same needs and motivations.

Referring to the tourism, the prosumer is an interactive person and a frequent traveler who is seeking experiences. For this reason, he is not interested in standard packages, which are reserved for the mass target demand (Chiam et al., 2009) rather he wants to live a travel experience, he wants to visit new places and be connect with local community. The prosumer is the new consumer with the following features: he is expert and aware about the travel he wants to do; he is careful to the price and quality relationship when he buys a travel package; he is critical and suspicious about some online reviewers; he knows very well what he needs and, when he browses on the web, he looks for a travel experience; finally he is not interested in massmarket standardized travel packages, rather he prefers an edutainment (education + entertainment) travel package (Gilmore \& Pine, 2007). This means that the prosumer is more oriented towards niche tourism services and packages which, as we are going to explain, are positioned in the "Long Tail".

This new kind of tourist becomes a new demand target who must be included inside the marketing portfolio of tourism brokers. If prosumer is an Internet user, consequently tourism brokers can find him on the web.

Nowadays, thanks to Internet developments, both travel agencies and TOs have directed some tourism product promotion and distribution strategies to this medium, using it as a means of communication and selling.

In this new social context, the tourism industry doesn't have the control of the communication, as in the past. The tourism industry has to build new communication methods: travel agents can start a peer-to-peer dialogue with tourists to find out their needs and desires, but also to learn how to improve their services thanks to feedback, reviews and comments. We are facing a new way of doing business, which involves relational skills in knowing how to listen and to talk, abandoning the "advertising monologues".

The worldwide spread of the Internet gave rise to the long tail theory (Anderson, 2006). According to Anderson, the long tail phenomenon began thanks to the web, because it allows one to reach all specialized or niche market communities with specific interests in order to sell desired services or products. Anderson declared that the on-line selling of niche services or products is better than that of mass services or products. The long tail theory bases on the changes of the distribution channels due to the Internet development. This change has been possible thanks to three forces that act in the long tail:

- First force: democratization of production tools, namely the dissemination of the means of production and sharing of content and information

- Second force: the democratization of distribution, ie the ability to deploy global services and information

- Third force: simplification of the link between demand and supply, or the possibility offered by community and word of mouth to find the right product or service - and therefore a proper producer that meets the needs of the consumer.

In comparison with the traditional distribution system, the on-line selling increases the number of suppliers and, consequently, of products and services available for an Internet users. Both big-sized and small-sized Internet players stand together on the Web becoming competitors one each others. It means that they need to distinguish their supply. This is true for all market sector, tourism included.

With his theory Anderson shows, in a graph, that even if, to some popularity products or services correspond an high number of demand, the highest selling volume and revenues are generated by the unpopular or niche products and services.

It is true because the popular products are available by the most suppliers, instead the unpopular ones are more lacking and more difficult in finding. Thanks to Internet development and the online distribution the niche destinations become more easily available to the on-line tourists (prosumer). It allows the small sized TOs reaching specific target demand and getting good revenues, as well. It means that a new business model is emerging. It is more not based on standardized and mass market products rather on customized ones. 
Referring to the small-sized US TOs selling Italy as main travel destination, the survey will going to demonstrate how they are applying the Anderson's long tail theory inside their marketing strategies. Their portfolio includes not only Italian popular destinations, but niche destinations too. We are going to demonstrate that niche destinations allow the TOs to distinguish their supply both with direct competitors (others TOs) and with the indirect ones (OTAs).

\section{Anderson's long tail graph}

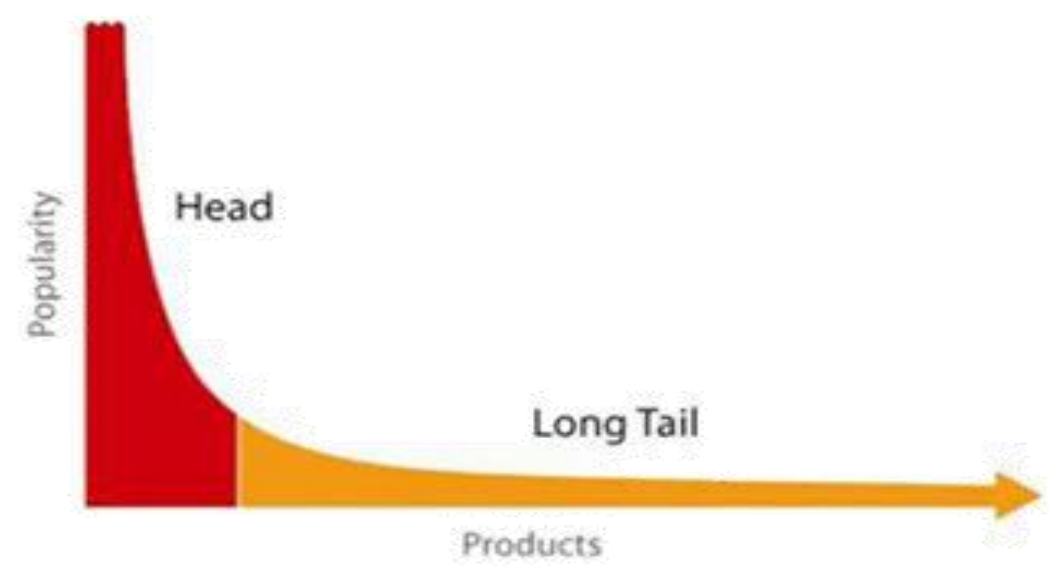

Figure 1. Anderson's long tail graph. Source: Anderson (2006).

The survey analyses the small-sized US TOs marketing mix (product, price and on-line promotion) and goes on with a comparison of the five big OTAs. This due because we want to discover what this two tourism brokers distinguish each other in terms of marketing mix strategies and what allows small-sized TOs to "survive inside that huge box" called World Wide Web.

As previous studies declare, thanks to Internet the ways in which tourism products are purchased and used have rapidly changed. It means that tourism demand behavior changed in terms of both life-style and product enjoyment (Pan \& Fesenmaier, 2006; Chung \& Buhalis, 2008; Ryan \& Rao, 2008; Tussyadiah $\&$ Fesenmaier, 2009; Buhalis \& Law, 2008).

Tourists buy a product after specific information searches, gaining a self-service mentality. They are able to put together a travel package using direct selling channels, telephone calls or any other means made available by ICT. In doing that, tourists are performing functions of TOs by assembling single elements of a trip into one package. With the increasingly convenient access to tourist service providers and information on Internet, this trend is always more popular thanks to the OTAs: the new tourist players born as a response to the tourism growth and market evolution. Browsing on an OTAs web site and to the dynamic packaging, tourist is now able to book a hotel on-line, or buy an airline ticket or rent a car. He decides how long to stay and where to go, sure of to form his own customized holiday package (Rachman \& Richins, 1997). In other words, tourist is able to create a basic travel package made of at least flight + hotel.

Some years ago this was what TOs made. The main TO's duty was to put together the basic tourist services as transportation and accommodation in a travel package and promote it to a travel agency. At the end of the 1990s in fact, the traditional tourism industry consisted of three main players: tourism services providers, tour operators (TOs) and travel agencies. By 2000, the Internet and the increasing technological tools multiplied the brokering levels and changed the relationships within the tourism industry (Buhalis, 2004; Litvin et al., 2008; Akehurst, 2009; Illu et al., 2010; Xiang \& Gretzel, 2010; Zeher et al., 2011). Because of this technological wave, tourism providers have gradually implemented innovations in the creation, promotion and selling of their products. The old commercial distribution and sales promotion strategies gradually declined and new marketing instruments emerged in the tourism industry (Cai et al, 2004; Huang et al, 2009; Xiang \& Pan, 2011; Kim et al, 2007; Della Corte \& Sciarelli, 2003). The traditional tourism industry doesn't exist anymore, rather the increasing number of direct and indirect competitors forced all tourist players, both the big and the small sized ones, to adapt or change 
their marketing strategies in order to survive inside the Internet Revolution.

As this survey is going to demonstrate U.S. tourism brokers, particularly small-sized TOs selling Italy as main travel destination, have tried to diversify and specialize their supply. They began to address a niche demand that seeks highly customized products and expert service able to meet the specific customer requirements (Trunfio et al, 2006; Klemm \& Parkinson, 2001; Medina-Muñoz et al, 2003; Bastakis et al., 2004). In this way, they have a dual role in a tourist destination marketing process: on the one hand their web sites become information sources for potential travelers, on the other hand they encourage and sell packages, customized or not, to everyone seeking high-quality expert service.

Previous studies (Woodside \& Lysonsky, 1989; Gartner, 1993; Baloglu \& Mangaloglu, 2001; Fría et al, 2008; Dioguardi, 2009; Li et al, 2009; Novelli \& Hellwig, 2011) have shown that TOs play a very important role in the image perception of tourism destinations, especially abroad, influencing the travel decisions of tourists.

In this way the survey demonstrates how they are changing their traditional role as tourism mass market player. If in the traditional tourist industry, TOs usually were mainly mass-market oriented, the casestudy we analyzed shows how this trend is changing. Because of the large number of tourist competitors and to the limited financial availability due to their small size, this kind of TO directs its offer to a new kind of tourist demand target in the attempt to remain competitive inside the World Wide Web. Rather than offering standardized travel packages in terms of mass market tourist destination, small-sized TOs offer new niche destinations, where it's possible to live an unforgettable travel experience made of smells; flavors; sounds and sensations which give an adding value to the travel.

This is what looks for the prosumer, who, for his behavior and socio-economic features, can be compared to the US on-line traveler wishing to leave abroad.

In the attempt to answer the previous four questions, the survey shows that TOs, especially the small-sized ones, are changing their traditional role as tourism mass market player. In fact they are directing their supply to niche market demand target, in particular to the prosumer, offering him customized travel packages sold and promoted direct on their web sites. On the other hand, big OTAs, like Expedia.com; Travelocity.com; Priceline.com, have always more control on mass market tourist. Their popularity, but, above of all, their high bargaining power on a large number of tourism service providers, allows them to reach the mass tourism demand, who looks for popular destinations which are placed on the head of the long tail graph. The dynamic package technique offered by OTA allows everybody to join two or more basic tourism service in a web-self-made travel package, questioning, in this way, the traditional TO's role.

\section{Survey Features}

Italy is one of the most desired travel destinations for non-European tourists, and this is particularly true for the U.S. outbound tourist market (ENIT, 2010). Despite terrorist attacks, Middle East wars, depreciation of the Dollar against the Euro, expansion of the global tourism market due to ICT development and the emergence of new competitor destinations, the U.S. tourist demand in Italy still maintains substantial arrival volumes, only behind those of the United Kingdom and France (OTTI, 2010). In fact, $89 \%$ of U.S. TO customers ask for travel information to Italy, even though the percentage of sold packages is only $30.1 \%$ (ISNART, 2010).

A study by the U.S. Travel Association (U.S. Travel Association and NLTeC, 2009) showed that the U.S. tourism demand seeks travel information using technological instruments such as search engines, service provider web sites (airline companies, hotels, etc.) and on-line tourism brokers (OTAs, TOs). This allows potential tourists to make bookings and obtain more specific information about a destination. Web 2.0-related sites are also used, e.g. virtual communities, social networks and usergenerated-content (UGC) sites, which encourage eword-of-mouth in which the user/tourist recounts his travel experience to others, becoming a promoter and a source of information. These data confirm that the U.S. tourist population uses the Internet as its main and preferred information source. In 2009, about $80 \%$ of the U.S. population stated that they had used the Internet to collect information for trip planning. After collecting information, $66 \%$ of them decided to make an on-line booking of the tourist product closest to what they required, using broker web sites or purchasing directly from the service provider web sites (ETC, 2010).

In comparing this data with the ENIT ones about the US tourist profile travelling to Italy (ENIT, 2010), we found a lot of similarities. Furthermore the same profile and behavior can be compared to the prosumer one (Toffler, 1981). Because of the large number of competitors being on Internet and in the attempt to catch niche tourist demand target, some small sized TOs have decided to widen their supply moving their interests to specific kind of product 
enjoyment. This was possible also thanks to the investment in new communication instruments and promotion channels, creating effective web sites to deal with both the business to consumer (B2C) and the business to business (B2B) relationships.

\section{Methods}

The survey is divided into four sections with the aim to investigate how US small-sized TOs stand along the long tail theory's graph.

The first section analyzes TOs web sites as promotion channel required by Anderson theory. Therefore, first of all it needed to identify the US small-sized TOs with a well-working web site to promote and sell travel packages on the Internet.

For this reason, we selected some small U.S. TOs specialized in promoting and selling Italy as the main destination in their product range. After obtaining a list of U.S. TOs selling travel packages to Italy from the Italian Tourism Agency (ENIT), we established selection criteria to create a panel of 11 TOs having the following common features:

- A web site with on-line product list.

- Yearly turnover around 5 million U.S. dollars

- Promotion of Italy as the only or main destination in their product list;

- Proposal of travel packages;

- Highly customized packages and services; Second section analyzes the TOs packages and their corresponding price. There were 104 selected packages in total with reference to the 2010/2011 online product list. A database containing the information on each variable was created (Atzeni et al., 2009), allowing us to analyze and summarize all the data.

The obtained graph will overlapped on the Anderson's long tail one.

Third section refers to Search Engine Optimization (SEO) analysis. As previous studies show (Cai et al, 2004; Pan et al 2011; Xiang \& Pan, 2011) to be online is not enough requirement.

TO needs to be noticed on the web, and for this, it must include a SEO analysis in its web marketing strategies.

Search engine results show different tourism players (OTAs, tourism service providers, social media) depending on the research criteria.
Considering a PhoCusWhright's research declaring that OTAs are the travel categories generating the major travel traffic volumes (PhoCusWhright, 2009), we decided to compare the US small-sized TOs with five big OTAs. This is due to the dynamic packaging that could allow an Internet user to create the same package supplied by a TO, using the OTA's web site. The PhoCusWhright's research appoints the seven top OTAs in the world, five of them are the most popular in US.

Forth section is a comparison with the five main OTAs. It refers to the attempts to assembly the same kind of travel services in a package as US small-sized TOs made.

\section{Section One: TOs' Web Site Promotion}

The on-line promotion of travel packages supplied by each TO web site was analyzed as essential element referring to the Anderson's long tail theory. According to the study by Cai, Card \& Cole (2004), the presence of 36 promotion elements in the sites were searched. The e-commerce elements were disregarded because they were not relevant to the aim of this survey.

The selected elements refer to Web 1.0 and 2.0 marketing tools. The study of the on-line promotion focuses on on-line information, promotion and sharing of contents, with reference to the $\mathrm{B} 2 \mathrm{C}$ relationship.

The survey evaluated the presence of some important web marketing tools in each TO web site. These web marketing tools were divided into three groups. Each value refers to the number of sites with that element.

The first, referred to as "information promotional tools", concerns not only the services provided by the TO but also the Italian landscape and historical attractions. This kind of information promotional tools were divided into three subgroups (Table 1):

1. This subgroup refers to tools providing information about the TO packages and travel services;

2. This subgroup refers to tools providing information about Italy as a travel destination;

3. This subgroup refers to tools providing information about the TO. 
Table 1. Web information promotional tools of the T.Os web sites.

\begin{tabular}{lr}
\hline Web information promotion tools selected in three groups & $\begin{array}{c}\text { T.Os number } \\
\text { using them }\end{array}$ \\
\hline Tools providing information about the T.O. packages and travel services & 11 \\
Packages offered & 11 \\
Prices per package & 11 \\
Itinerary per package & 8 \\
Departure dates and schedules & 10 \\
Optional activities (tours, transfers, daily activities...) & 8 \\
Price of optional activities & 6 \\
Special offers & 10 \\
Additional information on hotels & 10 \\
Customized packages & \\
Tools providing information about Italy as a travel destination & 6 \\
Historical-cultural information about Italy & 11 \\
Photos of Italy & 4 \\
Videos of Italy & 6 \\
Travel advice & 5 \\
Money exchange and/or weather conditions information & 4 \\
Events/News & \\
Tools providing information about the T.O. & \\
Information on the T.O. & 11 \\
Address of T.O. & 10 \\
E-mail contact & 11 \\
FAQ & 11 \\
\hline
\end{tabular}

The second group (Table 2), called "web marketing promotional tools", regards the on-line communication tools, referring to both Web 1.0 (newsletter, brochure downloads, etc.) and Web 2.0 (social networks, blogs; Really Simple Syndication
(RSS); video virtual trips, etc.). The aim of the survey was to understand if TO web sites act merely as a showcase or allow content sharing between demand and supply.

Table 2. Web marketing promotional tools of the T.O. web sites.

\begin{tabular}{lc}
\hline Web marketing 1.0 promotional tools & $\begin{array}{c}\text { T.Os numbers using } \\
\text { them }\end{array}$ \\
\hline Brochure download & 7 \\
Newsletter & 9 \\
Send e-mail to a friend & 5 \\
Client Testimonial & 7 \\
Media Testimonial & 5 \\
Social Network & 7 \\
Blog & 3 \\
Hot link membership & 7 \\
Feedback & 2 \\
RSS & 1 \\
Video Virtual Trips & 4 \\
Vertical Search & 8 \\
Mapping & 6 \\
Contextual Advertising & 3 \\
Podcasting & 3 \\
Tag & 3 \\
\hline
\end{tabular}


The third group (Table 3) refers to on-line services and action allowed to the clients by each TO's web site.

Table 3. Allowed on-line services and action.

\begin{tabular}{lc}
\hline B2C services & $\begin{array}{c}\text { T.Os number } \\
\text { using them }\end{array}$ \\
\hline Combination of products on-line & 6 \\
Booking on-line & 8 \\
Payment on-line & 7 \\
Verification on-line of available places & 4 \\
Control of booking status/purchase & 6 \\
Travel contract notice & 9 \\
Travel insurance notice & 8 \\
$7 / 24$ customer care service & 8 \\
Reserved clients web area & 7 \\
Partners reserved web area & 6 \\
\hline
\end{tabular}

The results show that all TOs use their web site as a promotional tool for their packages and to provide information about themselves. As promoters of the destinations and to make the travel packages more desirable, the TOs add photos of Italian historical monuments and landscapes to their web sites. Only 6 of the 11 TOs give cultural information about Italian historic monuments, and less than half provide travel tips or suggestions, for example: exchange rates, weather conditions, exhibits or cultural events happening in Italy.

Although all the TOs use their web site as a showcase for their product range, not all of them give detailed information about the travel packages, for example departure dates and schedules, daily tour details, additional information about accommodation, travel insurance or travel contract. Furthermore although all TO packages can be customized, this operation is not allowed on-line for all of them. Hence the user interested in a travel package must contact the TO directly by e-mail or by phone. Online booking of packages is allowed by 8 of the 11 TOs, but only 7 of them allow on-line payment.

The web site is also a customer care tool. Frequently asked questions (FAQ), a reserved customer area after registration, and a help-line to assist at any time are just some of the web marketing tools used by TOs. These tools reinforce both the $\mathrm{B} 2 \mathrm{C}$ relationship and the $\mathrm{B} 2 \mathrm{~B}$ relationship (e.g. public tourist agencies, media, brokers).

The most recent web marketing tools are also on the web sites. Newsletters $(90 \%)$ and brochure downloads $(70 \%)$ are the most common ones, while others are more unusual: mapping $(60 \%)$, contextual advertising (30\%), feedback (20\%), RSS (10\%). Some sharing tools are common, such as social networks $(80 \%)$, sending an e-mail to a friend (50\%), blogs $(20 \%)$, podcasting $(30 \%)$, tags $(30 \%)$, video virtual trips $(40 \%)$, which drive the e-word-of-mouth wave.

Finally some TOs try to create customer loyalty using on-line tools, such as "win a trip to Italy" with a competition prize draw; "buy and give a friend a $\$ 50, \$ 100$ or $\$ 200$ coupon". Some TOs use the web site as a communication platform thanks to a Skype contact by which the user can make direct on-line contact (call or video call) or verify that a TO operator is on-line or not. Furthermore $80 \%$ of TOs use the most popular social networks, such as Facebook, Twitter, Yelp and LinkedIn, to publish and share content concerning their products. Some links to YouTube, the most popular media sharing site, allow users to watch and share holiday videos.

The data on web marketing promotional tools allowed us to divide the TOs into four groups. (Figure 2).

TO's belonging to a group rather to another depends on the number of the promotional elements being on its own web site. The web sites contents refer to the groups and subgroups showed on Tables 1,2 and 3 .

The assigned criteria for each group were so established:

- Group 1 (18\%): TOs web sites having high information contents and using quite none web marketing tools;

- Group 2 (27\%): TOs web sites having high information contents and offering on-line customer services;

- Group 3 (46\%): TOs web sites having high information contents, offering on-line customer services and using some basic web marketing promotion tools merely the ones belongings to the Web 1.0; 
- Group 4 (9\%): TOs web sites having the high information contents, offering on-line customer services and using fully web marketing tools, from the basic ones to the more sophisticated.

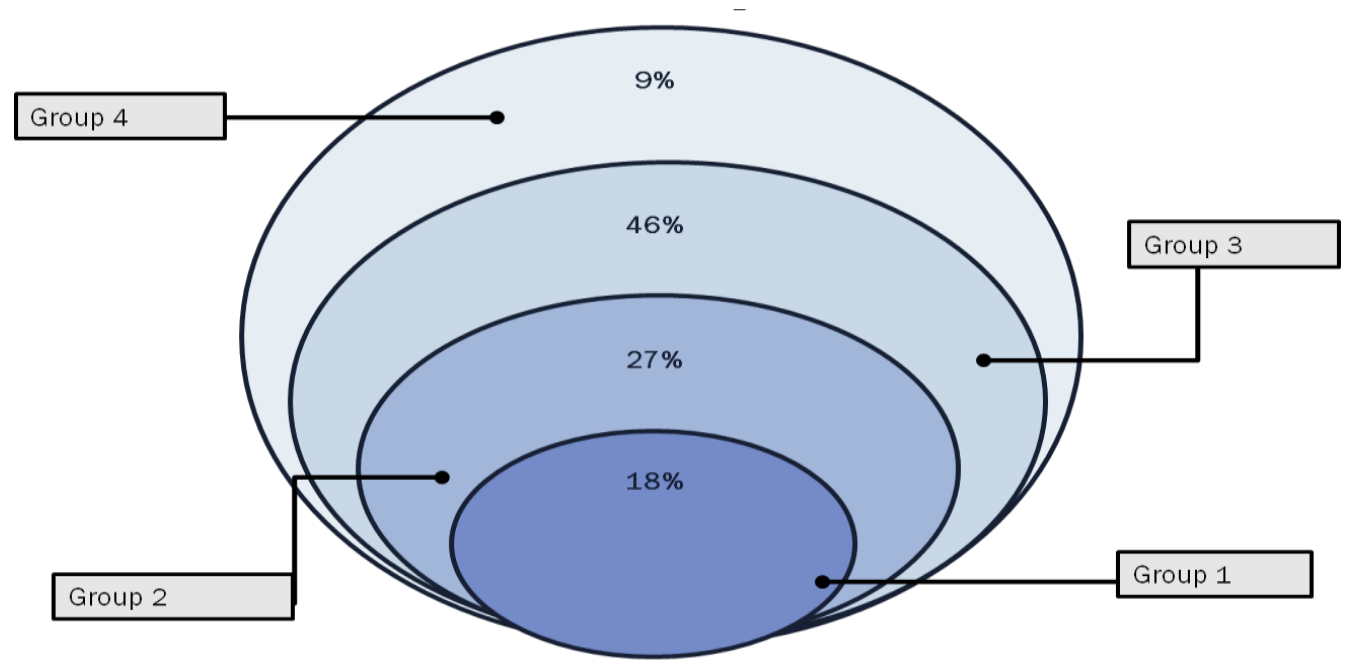

Figure 2. Classification of TOs according to their use of web site as an important marketing promotional tool.

Although all the TOs use their web site as an information showcase to promote the travel packages, only some of them fully benefit from the potential of the Internet as a distribution tool and as an interactive communication channel. Most TOs do not allow the tourist to put together services by himself. This is because they prefer direct contact with customers to supply personalized services that satisfy all specific needs.

\section{Section Two: TOs' supply}

Once we analyzed the web sites as promotional element to the base of long tail theory, it needs to know the packages with corresponding prices on-line offered by TOs.

In this section, first we are going to discover the promoted Italian destinations and what kind of services the packages include; second the proposed prices which depend on the popularity of the destinations and the services included inside the packages.

\section{Product}

Once we collected all data and inserted them into the database, the percentage presences of Italian cities or geographic areas supplied in the TOs' travel packages were calculated.

The cities or geographic areas were included in one of three destination groups (Ejarque, 2007):
A. Base tourism destinations: They have more than $30 \%$ presence in the travel packages. Their main feature is a high tourism load and a large number of tourist attractions well known to the U.S. tourism demand;

B. Transit tourism destinations: They have between $30 \%$ and $10 \%$ presence in the travel packages. Tourists visit them on their way to other final destinations. The visit is short, but tourist numbers can be very high;

C. Niche regional tourism destinations: They have no more than $10 \%$ presence in the travel packages. TOs supply these destinations to selected customers who have specific requirements and seek travel experiences away from the most popular Italian destinations.

There are many TO packages proposing visits to the three main Italian tourism cities belonging to the "turisdotto" (an Italian word referring to Rome, Florence and Venice). These three cities are included in the "Base destination" group because they appear in $69 \%, 52 \%$ and $43 \%$ packages, respectively. The Amalfi Coast belongs to the same group as well, because has $43 \%$ inside the TOs supply even if the accommodation iarealmost always situated in Sorrento, which serves as the base for day trips to Naples, Pompeii, Amalfi, Positano and Capri Island.

Many geographic areas both in the north and on the south of Italy belongs to the second group: the "Transit Destinations" one. Sicily is divided into 
two areas: north-western Sicily and south-eastern Sicily. This is because none of the packages supplies a tour of all of Sicily on account of its large size and the difficulty in reaching it from the other Italian regions (Dioguardi, 2009; Cuccia \& Rizzo, 2011; Cracolici \& Nijkamp, 2009). Catania and Palermo are the base cities from which the tours depart, directed to the south-eastern and north-western coasts of Sicily, respectively. The Sicilian locations most commonly visited during the tours are: Agrigento, Piazza Armerina, Taormina and Etna. Instead, Mazara del Vallo and Syracuse do not appear very frequently in the packages.

Like Sicily, also Tuscany can be divided into two areas: northern Tuscany and southern Tuscany. The packages to southern Tuscany involve stays in the Chianti-shire area. These tours usually leave from Florence, but sometimes from Rome as well, and visit Siena, San Gimignano, Volterra, Montepulciano and Monteriggioni, areas well known for their celebrated wines. Tours to northern Tuscany leave from Florence and visit Pisa, Montecatini and Lucca. Some tours, leaving from Rome and head toward Florence, avoid the Chianti-shire area and visit some umbrian cities (Assisi, Perugia and Orvieto).

Other cities belonging to the transit destinations group are Verona, Padua, Murano and Burano (locations next to Venice) or to Bologna, Modena, Reggio Emilia and Parma in Emilia Romagna.

Finally the Milan area in northern Italy is infrequently supplied in the packages. If the tour takes more than 10 days, these areas are usually included in it, but not in the other cases. The most visited northern areas are Milan and Lake Como, sometimes Lake Maggiore. Milan sometimes serves as the final destination for tours starting in Rome.
The third group "Niche destinations" includes destinations linked to specific interests and able to satisfy the customers' requirements. All of them form no more than $10 \%$ presence. These destinations have a very specific tourism orientation, such as wine \& food, folklore, seaside or an exclusive naturalistic or landscape aspect. For this reason, these packages are addressed to niche target demands with specific needs and looking for a new kind of high-quality travel away from the popular travel spots.

In northern Italy, the destinations including in this last group are Piedmont and the Liguria Coast. Leaving from Turin, these tours provide two kinds of holidays: the first is mainly related to wine $\&$ food, with visits to Monferrato and the Langhe area; the second involves both wine \& food and the seaside, because it spends several days on the Cinque Terre Coast. Lake holiday requirements are met with stays in the Lake Maggiore area.

In central Italy, TOs supply food \& wine packages in the Marche area.

In southern Italy, folklore and food \& wine packages are supplied in the Salento \& Gargano area and the Matera area. Seaside holidays involve the Tyrrhenian Calabria Coast and the Aeolian Islands.

The following figure reports the summary data, showing with a histogram, the three destination groups supplied by U.S. TOs and their corresponding percentages presences on the sum of the 104 packages analyzed.

The decreasing curve marking out of the histogram, reminds the Anderson's long tail curve.

Hence the attempt to overlap the two graphs in a whole figure. The resulting figure shows some evident similarities between the two graphs.

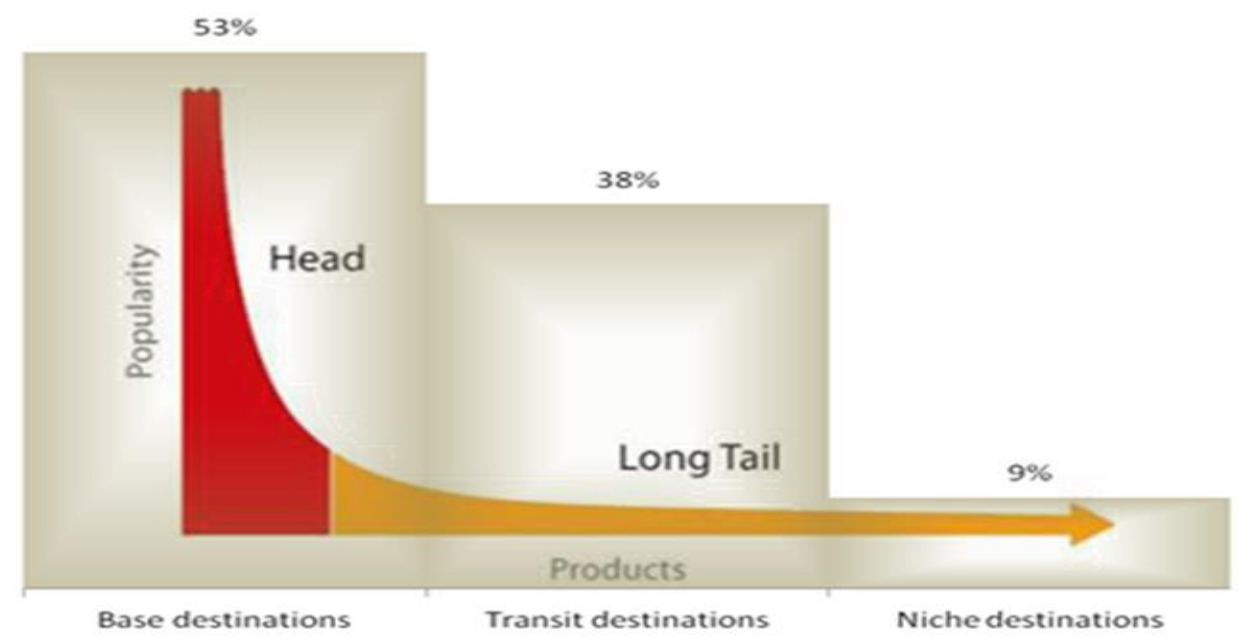

Figure 3. To destinations compared according to the long tail theory. 
In the tourism sector the popular products/ destinations can be placed on the head of the Anderson's graph and the unpopular ones, which usually are considered as niche destinations, can be placed on the tail of the same graph.

As Anderson declares, some popularity products or services correspond a high number of demand, the Italian destinations recording $53 \%$ percentages presences, coinciding with the "Base destinations" group, are those most required by customers and supplied by TOs. In the meantime we have to consider that each TO supplies at least one package including this destinations, so for this reasons, this kind of product has a lot of competitors and low prices as well. On the opposite side are the nichemarket destinations (only 9\%), coinciding with the "Niche destinations" group. Those are the same niche and un-popular products and services that Andersons declares as generating the highest selling volume. This is true because they are very competitive and, consequently, have a higher price than the base destinations packages. However, the TOs are tending to supply many packages $(38 \%)$ that combine popular Italian cities with unpopular tourist areas, included in the "Transit destinations" group. In this way, TOs are trying to reposition themselves within the tourism industry. Indeed TOs want to acquire a new image, no longer linked to a mass tourism demand, but to one of niche tourism. New destinations are proposed, both in the transit and niche packages, in order to satisfy the new customer requirements.

After identifying the more and less popular Italian destinations supplied by TO packages, we analyzed the additional services to clarify two aspects: the overall TO supply and the high added value in its package; some pricing choices which distinguish packages each other.

The more the services are targeted toward a given target, the higher is the price of the package and the more it can influence a potential customer to choose a TO package over another one.

Figure 4 shows the additional services, included in the final price, divided by type as follows:

- additional customer care services;

- daily tours and activities;

- meals;

- local transfers

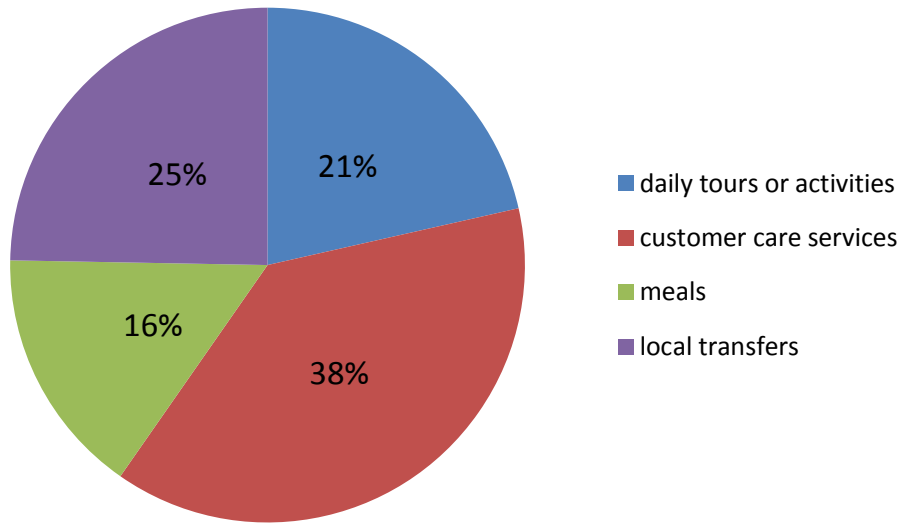

Figure 4. Additional services included in the final price of the packages.

These kinds of services provide the added value to the TO packages.

The daily tours or activities vary according to customer requirements. Guided museum or archeological area tours $(41 \%)$ are included in both cheap travel packages and expensive ones. Food \& wine tours $(28 \%)$ are supplied mainly in niche travel packages targeted at specific customers who seek not only a cultural visit but also the discovery of local traditions. Furthermore there are tours including cooking courses, craft workshops, theater or music shows, high fashion shopping and thermal spas.
These tours or activities have a dual function, benefitting both the tourist and the host population. As Novelli \& Hellwig (2011) pointed out for other destinations, the tourist has an experience that goes far beyond a simple stay at a destination, as he learns much about the host area, while at the same time the traditional customs and local folklore are kept alive.

The customer care services include tour guides $(27 \%)$ or, as an alternative, audio-guide recordings (11\%), baggage delivery (18\%), and museum or archeological area bookings (23\%). The last percentage is very low considering the high number 
of tourist attractions belonging to the Italian historical and cultural heritage, indicating that few TOs are involved in selling Italian cultural services. Furthermore it needs consider that museum or archeological area booking services are available only in the main cities such as Rome, Florence and Venice, not in minor destinations, and only one of the selected TOs includes in its core-business the booking of exhibitions, museums or any other event. Anyway, the traditional TO concept is changing. TO packages are no longer merely the flight + hotel (Della Corte, 2004), but now in its core business TO include hotels, villas, B\&B or farm accommodations + daily activities that meet the customer requirements. A few TOs (5\%) include gadgets, holiday souvenirs, travel insurance or document travel bags in the final price.

Meals included in the package price are usually dinner $(62 \%)$, while the lunch percentage is $38 \%$. No packages include meals every day.Finally many packages include local transfers such as itinerary point-to-point bus transfers $(42 \%)$, airport transfers $(25 \%)$, train transfers (7\%), domestic flights (2\%) and boat transfers (1\%). As an alternative to bus transfer, car rental or drivers can be requested.

\section{Price}

Price, as marketing mix variable of our US TOs analysis, refers to the weighted mean calculated from the sum of the product between price and number of days for each package in the product list of each TO. The following elements were analyzed for each TO: 1.position regarding the weighted mean calculated from the price and number of days for each package in the product list;

2. position regarding the mean daily charge;

3. range between minimum and maximum price for each TO's list of packages;

4. lowest, highest and mean selling-price for geographic areas/cities belonging to the three destination groups (Base, Transit or Niche destinations)

The weighted mean was assigned to each TO to create a hierarchy from cheapest to most expensive. The position of each TO is directly proportional to two factors. The first is the kinds of services provided, while the second is the exclusiveness and variety of destinations. The more a TO addresses a specific demand target, supplying thematic travel packages and stays in exclusive destinations away from popular tourism sites, the higher is its position in the hierarchy. The results confirm the desire of TOs to revise their role within the tourist industry, from a general mass-market player to a more specific niche-market oriented one.

Another price component is the mean daily expense charged to each U.S. tourist during the holiday. The resulting curve increases from a minimum of $\$ 205.00$ to a maximum of $\$ 433.00$ per person.

These data indicate that people travelling to Italy are usually in the middle-high U.S. socioeconomic class, earning between $\$ 50,000.00$ and $\$ 100,000.00$ per year. They are well-educated and without financial problems (ENIT, 2010). Usually they are high-spenders and certainly they have specific travel requirements and are interested in having an unforgettable holiday. As already declared, this tourist profile remind to the prosumer one.

From the analysis of the range between minimum and maximum travel package prices, we were able to distinguish two large TO groups. The first sells packages up to $\$ 3,000.00$, supplying mainly Base destinations travel packages and sometimes Transit destinations one. The second group is more expensive, with package prices up to $\$ 4,500.00$, but they supply a wide range of travel packages including all three destination groups (Base, Transit and Niche destinations). The package prices depend on the number of days, the kind of services and the number of additional services included. However, the highest package prices also depend on the kind of destinations and the customized services. The more the package provides a niche destination and personalized services, the higher is the price.

This is also shown by the selling price analysis (highest, mean, and lowest) for each city/geographic area supplied by the TOs. The results show that the base destinations have a large range between the minimum and maximum prices because they are supplied by both the cheapest TO and the most expensive one. In any case the mean price for base destinations is $\$ 2,300.00$. The situation is different for the other two types of destinations (transit and niche) which have more variable mean prices and ranges. The mean price for transit destinations is $\$ 2,750.00$ and for niche destinations \$2,975.00. Interesting is the high variability in price ranges due to the very low prices of some niche destinations like Marche $(\$ 914.00)$ or Matera $(\$ 2,239.00)$ on account of some targeted marketing strategies for the package start-up.

In the complex the analysis shows that TOs establish a low package price for the most popular destinations (base destinations), mostly chosen by tourists without specific requirements. It reminds the long tail theory declaring that to some popularity products or services correspond an high number of demand, but nevertheless the highest selling volume is generated by the un-popular or niche products and 
services. In TOs supply Niche destinations and Transit destinations packages are addressed to specific-interest targets, and the more the supplied destinations are unknown and away from the most popular and famous Italian cities, the higher is the price. Hence the price strategy is in inverse relation to the destination's popularity. Table 4 shows the three destination groups supplied by TOs. The data are the number of packages including that city or geographic area, the minimum, maximum and mean price per destination, and the percentage presence per destination.

Table 4. T.Os products and prices selected by destinations groups.

\begin{tabular}{|c|c|c|c|}
\hline Destinations & $\begin{array}{l}\text { Number of T.Os } \\
\text { sold packages }\end{array}$ & $\begin{array}{l}\text { Average selling } \\
\text { price }\end{array}$ & $\begin{array}{l}\text { Destinations } \\
\text { percentage presence }\end{array}$ \\
\hline Base Destinations & & $\$ 2.300,00$ & \\
\hline Rome & 72 & $\$ 2.305,78$ & $69,00 \%$ \\
\hline Florence & 55 & $\$ 2.263,33$ & $53,00 \%$ \\
\hline Venice & 45 & $\$ 2.392,47$ & $43,00 \%$ \\
\hline Amalfi Coast & 34 & $\$ 2.281,39$ & $33,00 \%$ \\
\hline Transit Destinations & & $\$ 2.750,00$ & \\
\hline Umbria & 24 & $\$ 2.552,49$ & $23,00 \%$ \\
\hline South of Tuscany & 23 & $\$ 2.411,68$ & $22,00 \%$ \\
\hline Verona \& Padua Area & 23 & $\$ 2.415,46$ & $22,00 \%$ \\
\hline Milan & 16 & $\$ 3.181,73$ & $15,00 \%$ \\
\hline South East Sicily & 15 & $\$ 2.779,82$ & $14,00 \%$ \\
\hline North of Tuscany & 14 & $\$ 2.814,14$ & $13,00 \%$ \\
\hline Modena, Reggio Emilia, Parma \& Bologna area & 12 & $\$ 2.715,45$ & $11,00 \%$ \\
\hline Como Lake & 11 & $\$ 2.930,79$ & $11,00 \%$ \\
\hline North West Sicily & 11 & $\$ 2.998,08$ & $11,00 \%$ \\
\hline Niche Destinations & & $\$ 2.975,00$ & \\
\hline Ravenna \& Saint Marino area & 8 & $\$ 2.664,83$ & $8,00 \%$ \\
\hline Cinque Terre area & 5 & $\$ 3.425,60$ & $5,00 \%$ \\
\hline Tyrrhenian Calabria Coast & 5 & $\$ 3.449,14$ & $5,00 \%$ \\
\hline Piedmont & 5 & $\$ 3045,85$ & $5,00 \%$ \\
\hline Maggiore Lake area & 3 & $\$ 3.819,00$ & $3,00 \%$ \\
\hline Salento area & 2 & $\$ 3.479,00$ & $2,00 \%$ \\
\hline Gargano area & 2 & $\$ 3.589,00$ & $2,00 \%$ \\
\hline Matera area & 2 & $\$ 2.239,00$ & $2,00 \%$ \\
\hline Aeolian Islands & 1 & $\$ 3.126,00$ & $1,00 \%$ \\
\hline Marche & 1 & $\$ 914,00$ & $1,00 \%$ \\
\hline
\end{tabular}

\section{Section Three: Search Engine Optimization}

A well-working interactive web site where promoting and advertising products on the Internet is a primary requirement to be on-line, but it is not enough. A TO needs to be noticed on the web and for this, it must include a SEO analysis in its web marketing strategies. If well done, it allows a web site to be easily traceable in the multitude of web pages on the Internet. Indeed some studies (Xiang et al., 2008; Xiang \& Pan, 2011; Law et al., 2010; Judd, 1995) and statistical data (US Travel Association, 2009) have demonstrated that a search engine is the most cost-effective web marketing tool, as it is very often used by Internet users searching for some kinds of information on the web.

This confirms the importance for a tourism player to place its web site among the first positions after a search engine query based on some specific keywords. First of all, it must understand the required criteria for a well-done SEO. It needs to find the right keywords, i.e. those most used by Internet users looking to travel to Italy. At the same time it needs to capture the attention of the specific target to which the TO wants to direct its products. The selected keywords that will help the TO web site be placed among the first positions of the search engine results must reflect the users' search behavior. Only in this 
way will it be possible to capture a specific target demand and advertise its web site on the Internet (Gursoy \& McLeary 2004).

Because of the importance of SEO, first of all in this section we are going to discover which the position is occupied by each TO in the Google.com search engine web page corresponding to the query "Italy Vacation".

The Google search results show not only OTA and TO web sites but also other kinds of web players (such as social media sites) distinguished according to the study by Xiang \& Gretzel (2010), as showing in Figure 5.

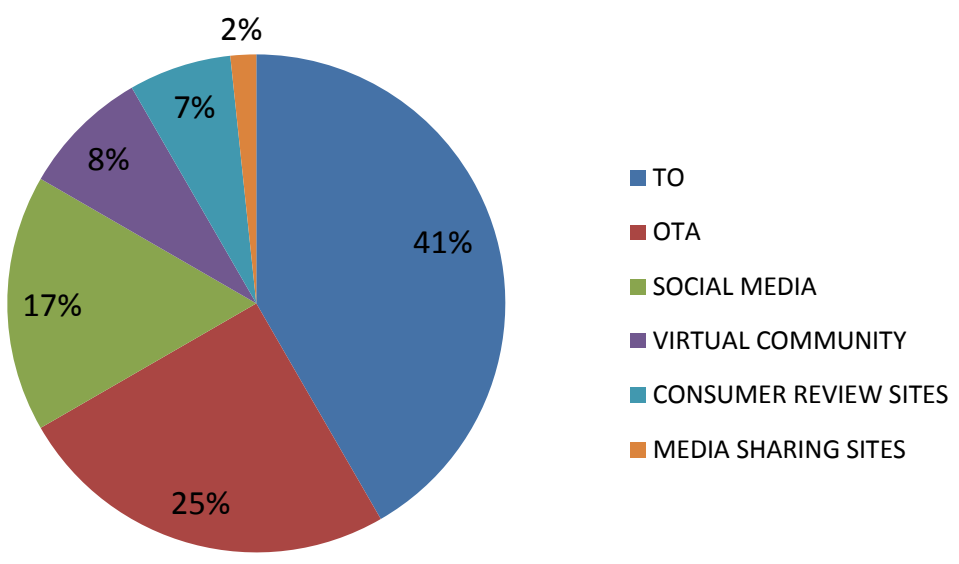

Figure 5. Google research results for the keyword "Italy Vacation"

On the basis of this results it assumes that when an Internet user looks for a vacation in Italy using the Google.com search engine web site and typing simple and basic keywords like "Italy Vacation", he easily access to a TOs web site as much as to an OTAs one.

Because of the emerging role of the OTAs which, thanks to dynamic packaging, allow their users to build a travel package as they requires, both for tourism services included and for the price, the second part of SEO analysis focus on OTAs and TOs. The aim is to understand how these two stakeholders appear in different way after the typing of different kinds of keywords. If it is true that to a generic and simple query like "Italy Vacation", the search engine Google.com web site shows quite the same number of TOs and OTAs web sites, it should be true as well that, the more the keywords are specific and targeted, the more the research results change. In the attempt to know how TOs can be found by potential customers by typing in some keywords into a search engine (Google, 2011), we selected some keywords that can help them to effectively place their sites on the Internet. The results were obtained using the online tool SEOCENTRO, with queries based on 20 keywords divided into two macro-groups (targeting and specific interest) To choose the keywords satisfying this aim, we used the on-line tool Google
AdWords. After typing the keywords "Italy vacation", it gave a list of related words. We then selected a panel of 20 keywords related to "Italy vacation", which were divided into two groups:

1. The first refers to keywords that could be typed by both a mass demand target and a niche demand target. The keywords refer to economic aspects (cheap Italy vacation packages, all inclusive Italy vacations, last minute Italy deals, luxury tours Italy, guided tours of Italy, independent tour Italy) characterizing the two macro-targets (mass and niche demand).

2. The second group refers to keywords allowing one to search for a holiday based on specific customer needs. For example, daily activities (wine tour Italy; cooking tour Italy; Italian cities guided tours; mini cruise tour Italy; honeymoon in Italy) or visits to specific Italian cities or geographic areas either well known or not by U.S. residents (Rome vacation packages; Venice vacation packages; Tuscany vacation packages; Sicily vacation packages; Cinque Terre vacation packages; Amalfi Coast vacation packages).

The results show that the more the keywords are specific, the higher is the TO's percentage presence among the first 50 Google search positions. In most cases, the TO web sites have a higher presence than the OTA sites. This is even more so for keywords referring to specific travel interests and for those 
referring to a visit to a niche Italian destination, both belonging to the second keyword group.

For the keywords in the first group, the data show that the presence of TOs or OTAs in Google.com changes depending on the kind of holidays searched for (cheap or expensive).

As Figure 6 shows, OTAs are well-placed in the Google search engine results for keywords referring to a mass demand target (first group of keywords) linked to low-cost trips, such as last-minute, deals, cheap. This confirms the mass market OTA orientation, supplying cheap prices and holiday deals. Instead, TOs are well-placed in the Google search engine results for keywords referring to packages (Italy vacation packages, all inclusive Italy, etc.) and niche travel (wine tour Italy, cooking tour Italy, luxury tours Italy, etc.).

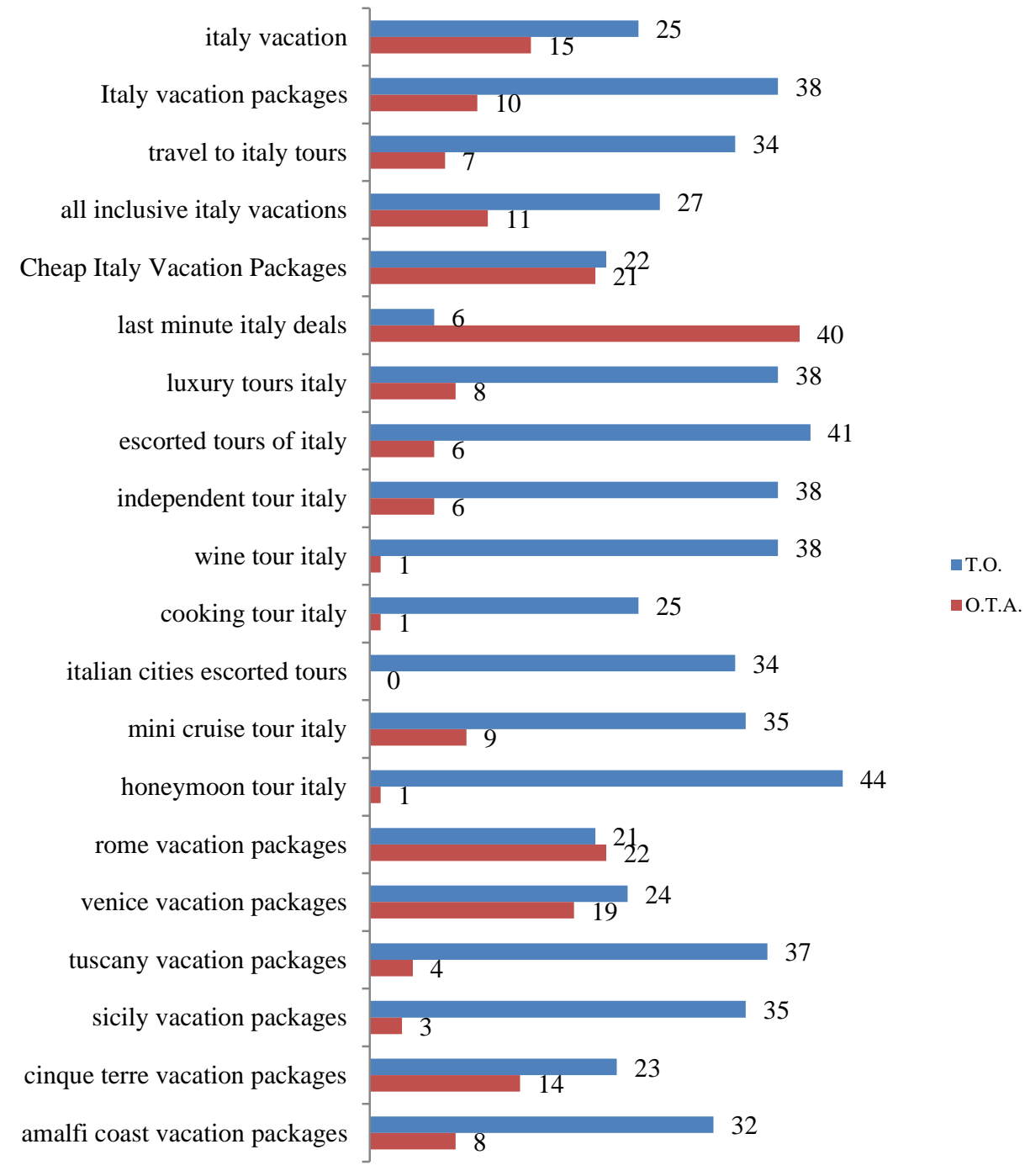

Figure 6. Search engine keywords for OTAs and TOs

The figure refers only to TOs and OTAs and does show other web sites included in the Google.com research results but not important for the purposes of our survey, even though they were considered during the data collection phase. Furthermore, although most of the TOs resulting from the Google search were from the U.S., there were also some from other countries (Europe, Canada, and Australia).

The last step of our analysis of SEO was to compare the presence of the five main OTAs with that of the U.S. TOs in the Google search results based on the same 20 keyword panel. The data show 
that Expedia.com is the OTA with the highest percentage presence, followed by Orbitz.com and Cheaptickets.com. Although Travelocity.com and
Priceline.com have lower percentage presences, their popularity with respect to the TOs should not be underestimated.

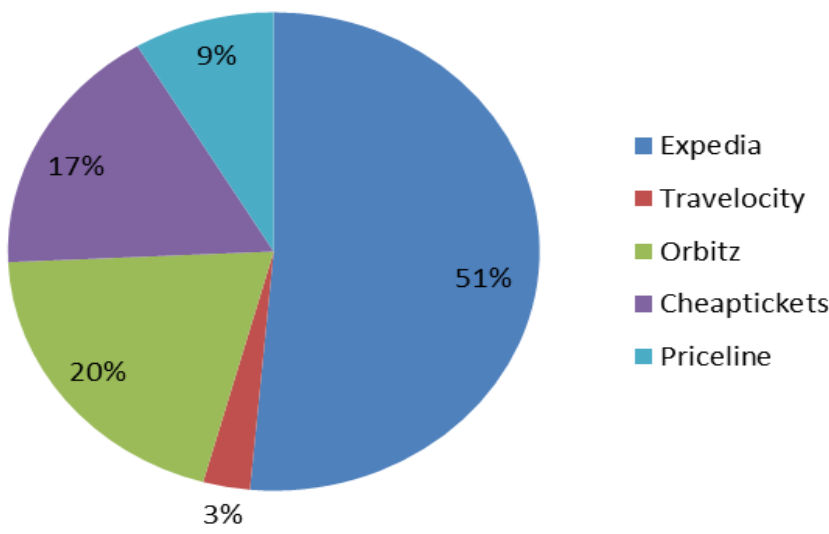

Figure 7. Percentage presence of the OTAs on Google.com.

\section{Section Four: Otas Comparison}

The data we collected since here allow us to declare that as a consequence of the Internet users behavior the tourist providers are directing their promotional marketing strategies through the web. Thanks to this new communication channel, the tourist providers are able to promote and sell their product directly to the final user. It implies lower costs, more clients to reach but more and new competitors direct and indirect as well. For small-sized TOs, Internet become a necessary tool to promote their supply and reach specific demand target. But, at the same time, Internet means also a lot of competitors, old and new, direct and in directs. In this regards we remind the Anderson theory declaring that the unpopular and niche products generate the highest selling volume. On the basis of this theory we are going to understand which are the differences between the products offered byTOs and OTAs. The attempt was to put together a travel package to Italy using the biggest and most popular OTA in the world: Expedia.com. We chose this OTA because its popularity and huge database allowing finding an enough quantity of tourist services to create a travel package. The aim was to answer the following questions:

1. Can any Internet user forego the work of a TO and uses an OTA web site to create the same kind of package we have just analyzed?

2. Are many geographic, logistic or technical skills necessary for an Internet user to put together a travel package by means of an OTA web site? And how much time would it take?

The re-creation of all the travel packages supplied by TOs using the OTA web site was not possible, and this was especially true for packages proposing Italian niche destinations.

The first step was finding the hotels in the TO packages. We obtained three results. First, it was easy to book a stay in the hotels in the TO packages belonging to the "Base destinations" group. Second, it was harder to find the hotels in packages belonging to the "Transit destinations" group. Third, it was impossible to find any of the hotels in the "Niche destinations" group packages because they are not included in the OTA database. Therefore we encountered many difficulties in the first step since only a few hotels were found using the OTA web sites and mainly those of the "Base destinations" packages.

After that, all the Italian destinations, part of the US small-sized TOs supply, have been searched inside the five main OTAs web sites, the mostly popular in US (PhoCusWhright, 2009). Some of the niche destinations were not inside the OTAs on-line database, furthermore the attempts to assembly the same kind of travel packages as the ones offered by the US small-sized TOs failed. This result allows assuming that is not possible booking any kind of travel on OTAs web sites, especially the niche ones. Anyway for the packages including the most Italian popular destinations we realized that in some case it was possible to create a sort of travelling package. So the next step was to create a travel itinerary package, 
like a point to point one from a city to another one of Italy. In doing that it needed to identify the best local transfer to move during the trip. Once again, we met with some difficulties.

First, it required detailed knowledge of the geographic locations of the Italian cities and the distances between them in order to choose the most suitable transfer service (train, rental car, domestic flight, etc.). Second, a lot of time was spent in Internet browsing during the travel package construction. The travel package is a more sophisticated product than a single-city tourist package. Putting together a travel package using an OTA web site requires a great deal of patience and much time to add on all the different tourism services. Finally, we attempted to combine the accommodation + transport with the additional services supplied by TOs, as some of these services were also found in the OTA web sites. There were no food \& wine tasting tours, nor cooking courses or craft workshops. Guided museum or archeological area tours were available, but only in the three main Italian tourism cities (Rome, Florence and Venice) and on the Amalfi Coast.

The failed attempt allows us to make some consideration: TOs and OTAs distinguish in their supply and it is not possible for an Internet users to create a travelling package offered by a TO using the biggest and most popular OTA web site. In doing that it needs huge geographical knowledge and technical skills. The same is for the packages offering stays in niche destinations. Hence, we are seeing a reversal of traditional tourism theory, as TOs and OTAs are changing their roles in the tourism industry.

TOs are changing from a general and massmarket orientation to addressing a niche market demand, supplying customized travel packages based on specific needs. OTAs are aiming mainly at visits to the main tourism cities, with special price deals (low-cost packages) targeting a "self-service" tourism target demand, i.e. the tourist who prefers to put together a travel package by himself, saving on the mark-up costs included in TO packages. The selfservice tourist does not seek an experience holiday. $\mathrm{He}$ is satisfied with visiting the main cities and does not need specific services; the basic ones (flight + hotels) are sufficient. In his requirement this kind of tourist in very different from the prosumer, whom TOs are targeting their travelling and niche destinations packages.

To validate this theory we are going to demonstrate how OTAs focus mainly on mass market destinations, figure 8 shows the percentage presence of hotels included in the five main OTA web sites database (Expedia.com, Travelocity.com, Orbitz.com, Priceline.com and Cheaptickets.com) distinguished by destination group. The graph focused only on the hotels in the Italian cities/geographic areas included in the TO packages, but it document how OTAs satisfy only "Base destinations" tourist demand.

The highest percentage (82\%) of hotels offered by the OTAs belongs to the "Base destinations" group, i.e. the TO destinations defined in Figure 3 as mass-market tourism destinations. Therefore the hypothesis of a reversal of the roles of TOs and OTAs within the tourism industry is confirmed.

TOs are tending to orientate toward a niche market tourism demand while OTAs are directing their supply to a mass-market tourism demand.

Reminding the long tail theory, it is possible to place OTA on the top of the graph, the area where are located the popular and cheap products (mass market); while TOs can be placed on the "tail" of the graph, the area where are located the un popular but more profitable products (niche market).

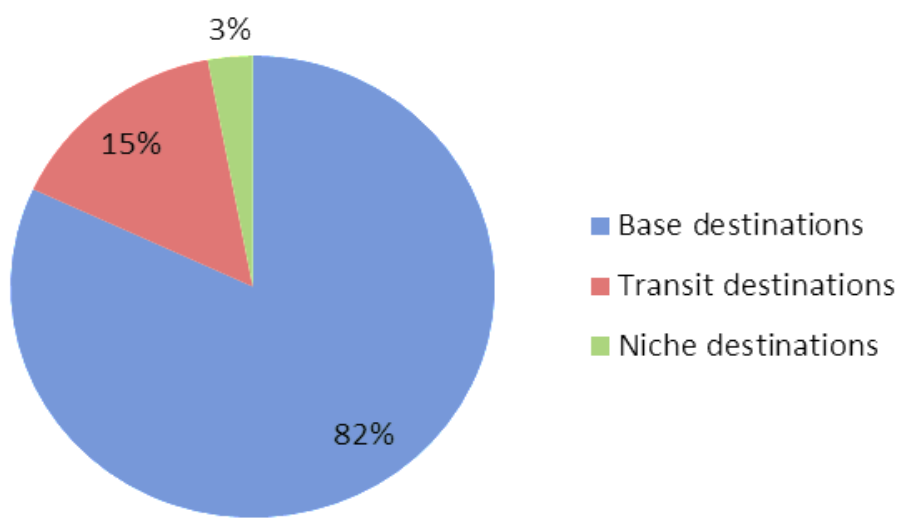

Figure 8. Percentage presence of the hotels in the OTA websites divided by destination group. 
The aim of our survey was to demonstrate the repositioning of small sized TOs and OTAs within the traditional tourism industry as a consequence to the market evolution due to ICT developments. Thanks to the spread of Web 2.0 applications and user generated content (UGC), traditional marketing tools are changing and web sites are becoming the means by which tourists are planning, booking and paying for a trip to Italy, which must be an exclusive, high-quality, customized experience.

With our web marketing mix analysis we demonstrate the birth of mass-market-oriented OTAs and the consequent change of the role of TOs toward a niche market orientation.

This sounds strange at first, a paradox, if we think about the history of tourism. In fact, TOs were established to standardize and industrialize the tourism sector, thanks to all-inclusive packages addressed to an off-line mass tourism demand. Instead, OTAs appeared thanks to the Internet, supplying tourism services that could be combined by the user himself and sold at cheaper prices than those of TOs. Using dynamic packaging technology, OTAs fulfill the user's dream to put together the package he requires, combining flights, hotels, local transfers and daily tours. However, our survey shows that this old view, i.e. mass-market TOs opposed to niche OTAs, is no longer valid. In fact TOs are renewing their product and price strategies. More exactly, referring to Anderson's theory, they are moving through the tail of the graph: the area where the highest selling volumes are generated by the un-popular or niche products and services.

Attention! As our survey shows, TOs direct their supply both to a mass and a niche target. But they differentiate the packages with different prices or different destinations to visit. In this way, they attract a new demand target and distinguish themselves from the competing OTAs. This is thanks to the TOs' capacity for innovation, adaptation to market changes and professional expertise acquired through the years. Furthermore, unlike OTAs, they provide consulting and professional know-how during the assembly of tourism services making up the package, aiming to satisfy all the customer's travel needs. This is an important TOs feature: the additional value of a product-package supplied by a TO is the tourist's experience during the trip, which is determined by the additional services. The TO's package does not consist only of the flight + hotel + rental car, as does the OTA's package. The TOs offer the chance to have a travel experience, allowing the tourist to discover various aspects of a resort, such as cultural traditions, food \& wine, entertainment or folklore. Furthermore, the tourist does not have to worry about organizing the trip or about transfers or incidental mishaps. Everything depends on the TO management, whose main purpose is customer satisfaction and retention. These services complete the travel packages and they allow us to understand some pricing choices and the differences between the travel experience supplied by a TO and a self-service trip organized on an OTA web-site.

Instead, OTAs direct their supply mainly to a mass-market tourism demand looking for special lastminute deals and low-cost travel packages. These kinds of tourism products are available on the OTA web sites and they usually have lower prices than TO products. Tourists are able to combine the services they require by themselves thanks to dynamic packaging technology, but this is true only for the main and popular Italian tourist cities, not for niche destinations.

Unlike TOs, OTAs supply does not include customized services to satisfy specific customer needs and it is difficult for any user to create a travelling package point to point by a city to another using the dynamic packages system.

This is what distinguishes the TO supply: it gives the tourist a full holiday experience. It is not possible to put together the same package using an OTA web site, as profound knowledge of the territory and strong organization are required to assemble all the "pieces of the puzzle", i.e. the single services composing the package. Furthermore, some niche destinations can be found only in that single TO product list, not in those of the TO competitors or the OTAs. Indeed the competiveness of TOs with respect to OTAs depends on this. Although OTAs have cheaper prices than TOs, they do not supply and sell experience holidays but rather single tourist services which must be put together by the tourist himself.

There are two opposite kinds of Internet-using tourists. The first is the mass market tourist who looks for the cheapest holiday deal, while the second is the niche market tourist who wants to have a travel experience and has specific needs. This last kind of tourist is the prosumer, who can be compared to the one choosing a TOs package. He is producer and consumer in the same time. Producer because he wants to live a travel experience, consumer because he enjoy the travel experience. The prosumer, choosing a TO travel package is both who enjoy a first holiday in Italy and for whom it is sufficient to visit the main Italian cities, but he can be also a tourist who has already been to Italy at least once and, in coming back, is looking for high quality and new kinds of experiences for maximum holiday enjoyment.

He does not require a mass product but the niche ones, and he is ready to pay more to get and enjoy this kind of travel package. This is a tourist who 
redefines the concept of "luxury", which no longer means opulence, ostentation and abundance but rather experience (Stamboulis \& Skayannis, 2003; Morcellini, 2003). It demonstrates the wide variability of minimum and maximum prices fixed for "turisdotto" and Amalfi Coast destinations. In fixing prices TOs direct both to thrifty tourists and well-off ones, the both are able to enjoy a trip to these locations. The services provided make the difference. A simple package combining hotel + local transfer is addressed to the former kind of tourist (thrifty). However the package proposed to the latter tourist type (well-off) includes high-quality facilities and additional services including both customer care and tours or daily activities, which improve the overall travel experience.

Our analysis shows that OTAs direct their supply mainly toward the mass-market and low-cost tourism demand. Thanks to the dynamic packaging and to the large number of tourism service providers included in their databases, they can fix low prices. OTAs price strategy is: the more tourists services you buy the most you save. In this way any user can choose the most convincing providers to the cheapest price. The final package can be purchased on the Internet and it is cheaper than that of TOs because it does not include mark-up or brokerage costs. At the same time, the Internet also allows players to reach niche markets, but in doing that TOs needs a well-working web sites where promoting and selling their travel products.

Our analysis shows that, probably due to size and economic reasons, TOs do not have a welldeveloped web sites as OTAs. Not all U.S. TOs use e-commerce tools to make on-line commercial transactions. Just 7 of the 11 sites allow customers to buy the packages on-line without specialized help. Packages are booked most often by e-mail or by phone via the web site, and these actions lead to the final transaction. Most TOs prefer to help the customer put together the services in the package directly by phone. Confirmation of bookings and checking the status of the order can be done either by web site or by phone. People can also use the web sites to read the travel insurance or contract conditions, actions needed to finalize the transaction.

Therefore, with respect to the five main OTAs used by U.S. tourists, the orientation of TOs to online selling is low and they prefer direct contact with the final customer by phone or e-mail for bookings and payments. The web site is usually an advertisement tool and a gateway to the initial relationship with customers. Direct contact between customer and TO begins only when a customer is really interested in a TO package. After registration on the site, the customer is allowed access to the area reserved for him; during the trip, he can receive help wherever he is or whenever he wants thanks to the on-line customer care service. In addition, the web site is often a gateway for relationships with other tourism players.

These are the main functions of the on-line distribution marketing mix variable. TOs use their web sites as first contacts with customers but then prefer a "face-to-face" relationship possible thanks to phone and e-mail services. This allows TOs to understand what the customer is looking for and thus to satisfy his specific needs. On the demand side, the user not only delegates the to put together the travel package he desires, but he is always sure of customized service in each travel phase. The TO's aim in providing this service is good customer satisfaction and retention.

The use of web sites mainly as an "access gate" to the customer contact is another feature distinguishing the TOs role with the OTAs one. From a customer care point of view, having a web sites with few or none e-commerce tools, is wanted TOs choice, in the willing to do not leave the user alone during Internet browsing but rather guide and help him whenever he needs assistance. This is very important especially for niche destination packages supplying stays in small and unpopular Italian cities, which require specialized consulting and territorial know-how guidance. OTAs do not have this kind of knowledge because their role is merely to broker the single tourist services which are put together in a travel package by the user thanks to dynamic packaging technology and a high-tech web site.

Therefore we are witnessing a reversal of the roles of TOs and OTAs within the tourism industry and it is due to the development of the Internet.

The obtained results allow finding answers to the questions we raised in the introduction section. Furthermore the results confirm the study by PhoCusWright (2009) showing that the changing role of TOs toward a niche market orientation is in line with the decreasing mass market tourism demand. Although the OTA web sites are browsed more than the TO sites, Expedia, Orbitz, Cheaptickets, Travelocity and Priceline recorded fewer web users and customers in 2009 than in previous years. In particular, the number of Internet users booking a trip on one of these OTA web sites decreased from $79 \%$ to $72 \%$ in two years.

Our survey shows that it is easier to book a flight or hotel room involving popular Italian cities like Rome, Florence or Venice. However it is harder, using an OTA web site, to book a stay in small Italian tourism cities or villages and to enjoy an experience holiday. Therefore, U.S. TOs are focusing their marketing strategies on this aspect. They are 
becoming promoters and suppliers of niche travel packages, favoring special interest holidays away from the most popular Italian tourism destinations. In this way, they give international notoriety to lesser known tourism destinations and they differentiate their supply from that of OTAs, remaining competitive in the growing global Internet market.

\section{Management Suggestions}

Country Brand Index 2011 includes the search for experiences, customized trips away from popular destinations and Internet use in trip planning as emerging tourism trends. In the light of these developing tourism trends and the results of our survey, we propose some suggestions that might help Italian incoming tourism players in their future web marketing strategies.

The Internet is undoubtedly the best tool to promote and advertise the player's product to a wide international audience. Improving and streamlining the web site will provide many benefits and opportunities: communication and promotion of the product using cheap and popular tools; strengthening the $\mathrm{B} 2 \mathrm{~B}$ and $\mathrm{B} 2 \mathrm{C}$ relationships; monitoring the purchase-consumption behavior of the desired tourism target; checking the marketing strategies of direct and indirect competitors. Finally, as a great communication tool, the Internet allows consumers to share their experiences with other consumers $(\mathrm{C} 2 \mathrm{C}$ relationship), favoring e-word-of-mouth. The kinds of travel packages supplied by TOs allow them to reposition themselves along the long tail theory curve.

Some of the U.S. TOs selected in this survey took full advantage of the Internet development. Just as these TOs discovered the power of the Internet to supply experiences through high-quality travel packages and thus became oriented toward a niche market demand, Destination Management Organizations (DMOs) can use this example to readdress or remodel the image of their territory toward a specific-interest tourism target. To this purpose, a DMO can strengthen and improve its web site, making it more streamlined and interactive (Costa \& Testa, 2012). Choosing the right broker is also very important, as it must be able to promote and sell destinations in the best way possible.

By using the Internet, both TOs and OTAs can give broad visibility to the DMO. Yet it must be careful in deciding to which target it wishes to address its product? Choosing one kind of broker rather than another determines the DMO's position along the long tail theory curve. Hence, the destination will be more oriented either toward a mass market tourism demand enjoying a low-cost holiday or toward a niche tourism demand looking for quality services and experiences.

The same thing is true for accommodation providers within a destination. Like other tourism players, they can choose which position to take along the long tail theory curve. Being on an OTA web site means that a large number of Internet users can gain access to the accommodation provider's web site, but this high visibility has its price in terms of dependence of the accommodation provider on the OTA's bargaining power and on the type of massmarket tourism demand enjoying low-cost and shortbreak holidays.

This trend further confirms our theory about the TOs repositioning. Their traditional role within the industry (Poon, 1993; Shaw \& Williams, 1994) and their subordinate relationship both with the tourism destinations and with the accommodation at the destination (Medina-Muñoz, Medina-Muñoz \& Falcón, 2003) cannot be supported anymore . As data demonstrate, OTAs now have high contracting power over accommodation providers in the main Italian cities. For example, Expedia.com proposes about 1641 hotels in Rome, but only 36 accommodation facilities in the Cinque Terre area.

As a window on the World Wide Web, Expedia.com and many other OTAs give great visibility to the accommodation providers in the database. However, this creates a strong tie of dependence between OTAs and the providers, as occurred in the past between mass-market TOs and destinations.

This shows how important the marketing mix strategies are for Italian incoming tourism players. DMOs and small-medium-sized enterprises (SMSE) that have not acquired management skills concerning recent tourism market developments run the risk of disseminating a tourism image or product different from what they desire. If they are unable to recognize the differences between OTAs and TOs as brokers, they may not be able to identify Internet opportunities or threats. Therefore each tourism player must consider the evolution that traditional Travel \& Leisure market theories are undergoing. Only then will the player be able to decide on the position to take along the long tail theory curve.

\section{References}

Aguilò P. M., Alegre J. \& Riera A. (2001). Determinants of the price of German tourist packages on the island of Mallorca. Tourism Economics, 7 (1), 59-74.

Akehurst G. (2009). User-generated content: The use of blogs for tourism organizations and tourism consumers. Service Business, 3, 51-61.

Anderson C. (2006). The long tail. Why the future of business is selling less of more. Hyperion Press, New York. 
Andreau L., Aldás J., Bigné J. E., \& Mattila A. S., (2010). An analysis of e-business adoption and its impact on relational quality in travel agency-supplier relationships. Tourism Management,31 (6), 777-787.

Atzeni P., Ceri S., Paraboschi S. \& Torlone R. (2009). Basi di dati, modelli e linguaggi di interrogazione. Ed. McGraw-Hill, Milano.

Au A. (2010). Adoption of web 2.0 by tourism. Business in NSW

Baggio R. \& Corigliano M.A. (2006). Tourism, technology, information \& relationship with customers. Tourism Management, 27, 890-900.

Baloglu S. \& Mangaloglu M. (2001). Tourism destination images of Turkey, Egypt, Greece and Italy as perceived by US-based Tour Operators and Travel Agents. Tourism Management 22 (1), 1-9.

Bandulet M. \& Morasch K. (2003), Would you like to be a prosumer? Information revelation, personalization, successful products and services, International Journal of The Economics of Business, 12(2), 251-271.

Barnett M. \& Standing C. (2001). Repositioning travel agencies on the Internet. Journal of Vacation Marketing, 7 (2), 143-152.

Bastakis C., Buhalis D. \& Butler R. ( 2004). The perception of small and medium sized tourism accommodation providers on the impacts of the tour operators' power in eastern Mediterranean. Tourism Management , 25 (2), 151-170.

Beldona S. (2005). Cohort analysis of online travel information search behavior: 1995-2000. Journal of Travel Research, 44 (2), 135-142.

Buhalis D. (1998). Strategic use of information technologies in the tourism industry. Tourism Management, 19 (5), 409-421

Buhalis D. (2000). Relationship in the distribution channel of tourism: conflicts between hoteliers and tour operators in the Mediterranean region. International Journal of Hospitality and Tourism Administration, 1 (1), 113-119.

Buhalis D. (2004). E-Tourism: information technology for strategic tourism management. Annals of Tourism Research, $31,740-741$

Buhalis D. \& Jun S. H. (2011). E-tourism. contemporary tourism review. Goodfellow Publishers Ltd, Oxford

Buhalis D. \& Law R., (2008). Progress in information technology and tourism management: 20 years on and 10 years after the Internet-the state of e-tourism research. Tourism Management, 29(4), 609-623.

Buhalis D. \& O'Connor P. (2005). Information communication technology revolutionizing tourism. Tourism Recreation Research, 30 (3), 7-16.

Buhalis, D. \& Licata, M. C. (2002). The future e-tourism intermediaries. Tourism Management, 23 (3), 207-220

Cai L., Card J. A. \& Cole S. T. (2004). Content delivery performance of World Wide Web sites of U.S. tour operators focusing on destinations China. Tourism Management 25, (2), 219-227

Carroll, B., Siguaw, J. (2003). The evolution of electronic distribution: effects on hotels and intermediaries. Cornell Hospitality Quarterly, 44(4), 38-50.

Cavelek N. (2000). The role of tour operators in the travel distribution system. In W. C. Gartner \& D. W. Lime (Eds), Trends in outdoor recreation, leisure and tourism. New York: CAB International

Chabot A. (2007). Travel 2.0: Future of tourism? An investigation into web 2.0 and its impact on the travel and tourism industry. MA European Tourism Management, Bournemouth University-Fachhochschule Heilbronn.

Chiam M., Soutar G.,\& Yeo A.(2009). Online and Off-line Travel Packages Preferences: A Conjoint Analysis. International Journal of Tourism Research, 11, 31-40.

Choi S., Lehto X. Y. \& Oleary J. T.,(2007). What does the consumer want from a DMO Website? A study of US and Canadian tourists' perspectives. International Journal of Tourism Research 9, 59-72.
Christodoulidou N., Connolly D. J \& Brewer P., (2010). An examination of the transactional relationship between online travel agencies, travel Meta sites, and suppliers", International Journal of Contemporary Hospitality Management, 22(7), 1048 - 1062.

Chung J. Y. \& Buhalis D. (2008). Information needs in online social networks. Information Technologies and Tourism ,10, 267-281

Clemons E.K., Hann I.H. \& Hitt L.M. ( 2002). Price dispersion and differentiation in online travel:an empirical investigation. Management Science, 48 (4), 534-549.

Corigliano M. A. \& Baggio R. (2011). Internet e turismo 2.0. tecnologie per operare con successo. Egea, Milano

Costa N. (2005). I professionisti dello sviluppo turistico locale, Milano, Hoepli.

Costa N. \& Testa S. (2012). Web marketing e destinazione ospitale. Teorie e metodi per la promozione $e$ commercializzazione dell'esperienza turistica. Milano, McGraw-Hill.

Cracolici M. F. \& Nijkamp P., (2009). The attractiveness and competitiviness of tourist destinations: a study of Southern Italy Region. Tourism Management, 30, (3), 336-344.

Cuccia T. \& Rizzo I., (2011). Tourism seasonality in cultural destinations: An empirical evidence from Sicily. Tourism Management, 32 (3), 589-595.

Della Corte V., (2004). La gestione strategica e le scelte di governo di un'impresa "tour operator". CEDAM, Padova.

Della Corte V. \& Sciarelli M., (2003). Evoluzione del marketing nella filiera turistica: Il ruolo dell'information \& communication technology. Congresso Internazionale "Le tendenze del marketing" Università Ca' Foscari Venezia, $11 / 28-29$.

Dioguardi V. (2009). L'immagine della destinazione turistica come costruzione sociale. Franco Angeli, Milano.

Egger R. \& Buhalis D. (2008). E-Tourism case-studies: management and marketing issues. Elsevier, Oxford

Ejarque J. (2007). La destinazione turistica di successo. Hoepli, Milano.

ENIT (2010). Rapporto ENIT/MAE 2009 STATI UNITI. In http://www.enit.it/en/studies-and-research/country-focus/cate gory/7-pp.html.

ETC (2010). Market Insight United States July 2009. In http://www.newmediatrendswatch.com.

Frías D. M., Rodriguez M. A. \& Castañeda A. (2008). Internet vs travel agencieson pre-visit destination image formation: an information processing view. Tourism Management 29 (1), 163-179.

Gartner W. C. (1993). Image formation process. Communication and Channel System in Tourism Marketing, 191-215.

Gartner W. C. \& Bachri T. (1994). Tour operators' role in the tourism distribution system: an Indonesian case study. Journal of Travel Research, 23 (3), 2-7.

Gilmore J.H. \& Pine J. (2007). Authenticity. What consumer really wants. Boston, Harvard Business Press.

Google (2011). Guida introduttiva di Google all'ottimizzazione per motori di ricerca. Reterived from: http://www.google.com /int1/.../search-engine-optimization-starter-guide-it.pdf.

Granieri G. (2006), La società digitale, Bari, Editori Laterza

Granovetter M. \& Swedberg R. (2011). The Sociology of Economic Life. Boulder CD, Westview Press.

Granovetter M. (1983). The Strength of weak ties: A network theory revisited. Sociological Theory, 1:201-233.

Granovetter M. (2005). The impact of social structure on economic outcomes. Journal of Economic Perspectives 19 (1), 33-50.

Grassini S. (1999). Dizionario dei New Media. Milano, Raffaello Cortina.

Grasso M. (2009). Tour operator e agenize dettaglianti: Strategie e marketing delle imprese di viaggio. Franco Angeli, Milano

Guizzardi A. \& Mazzocchi M. (2010). Tourism demand for Italy and the business cycle. Tourism Management, 31, 367-377. 
Gursoy D. \& McLeary K.W. (2004). An integrated model for tourists' information search behavior. Annals of Tourism Research, 31 (2), 343-373.

Huang L., Chen K.H. \& Wu Y.W. (2009). What kind of marketing distribution mix mix can maximize revenues: the wholesale travel agencies perspective? Tourism Management 30, (5), 733-739.

Illum S. F., Ivanov S. H. \& Liang Y.(2010). Using virtual communities in tourism research. Tourism Management 31 (3), 335-340

Inkpen G.(1998). Information Technology for Travel and Tourism, Longman, Singapore.

ISNART (2010). Impresa Turismo 2010. Reterived from: http://www.isnart.it/bancadati/index.php.

ISNART (2010). Indagine sul turismo organizzato internazionale 2009. Reterived from: http://www.isnart.it/bancadati/ schedaDoc.php?id=141.

ISNART (2010). Le performance di vendita delle imprese del ricettivo. Quarto trimestre 2010. Reterived from: http://www.isnart.it/bancadati/schedaDoc.php?id=195.

ISNART (2011). Impresa e turismo 2011. Reterived from: http://www.isnart.itbancadati/index.php.

ISNART (2011). Indagine sul turismo organizzato internazionale 2010. Reterived from: http://www.isnart.it/bancadati/scheda Doc.php?id=175

Judd D. R. (1995). Promoting tourism in US cities. Tourism Management, 16, 175-187.

Karamustafa K. (2000). Marketing-channel relationships: Turkey's resort purveyors' interactions with international tour operators. The Cornell Hotel and Restaurant Quarterly, 41 (4), 21-31.

Karakas F. (2009). Welcome to World 2.0: The new digital ecosystem. Journal of Business Strategy, April, 2009, 23-30.

Kenneth J.W. (1985). An international travel demand model. US travel to Western Europe. Annals of Tourism Research, 12 (4), 529-545

Kim D.Y., Letho X.Y. \& Morrison A. M. (2007). Gender differences in on-line travel information search: implications for marketing communications on the internet. Tourism Management 28, (2), 423-433.

Klemm M. \& Parkinson L., (2001). UK tour operator strategies: causes and consequences. International Journal of Tourism Research, 3, 367-375.

Law R. (2000). Internet in travel and tourist- Part 1. Journal of Travel \& Tourism Marketing 9 (4), 83-87

Law R., Law A. \& Wai E. (2001). The impact of the internet on travel agencies in Hong Kong. Journal of Travel \& Tourism Marketing, 11 (2/3), 105-126.

Law, R., Leung, K. \& Wong, J. (2004). The impact of the internet on travel agencies. International Journal of Contemporary Hospitality Management, 16(2), 100-107.

Law R., Leung R. \& Buhalis D. (2009). Information technology application in hospitality and tourism: a review of publications from 2005 to 2007. Journal of Travel \& Tourism Marketing 26, 599-623.

Law R., Qi S. \& Buhalis D. (2010). Progress in tourism management: a review of web evaluation in tourism research. Tourism Management, 31, 297-313

Li X., Pan B., Zhang L. \& Smith W.W. (2009). The effect of online information search on image development. Journal of Travel Research, 45-57.

Litvin S. W., Goldsmith R. E. \& Pan B., (2008). Electronic wordof-mouth on tourism website in hospitality and tourism management. Tourism Management, 29 (3), 458-468.

Medina-Muñoz D. \& Garcìa-Falcòn J.M. (2000). Successful relationship between hotels and agencies. Annals of Tourism Research, 27 (3), 737-762.

Medina-Muñoz R.D.; Medina-Muñoz D.R. \& García-Falcón J. M.(2003). Understanding European tour operators' control on accommodation companies: An empirical evidence. Tourism Management 24 (2), 135-147.

Milani R., Baggio R. \& Pittarelli R. (2011). The effect of online social media on tourism website. $18^{\text {th }}$ International Conference on Information Technology and Travel \& Tourism, Innsbruck, Austria, 01/26-28.

Morcellini M. (2003). Lezioni di comunicazione. Nuove prospettive di interpretazione e di ricerca. Ellissi, Napoli.

Novelli M. \& Hellwig A. (2011). The UN Millennium development goals, tourism and development: The tour operators' perspective. Current Issues in Tourism, 14 (3), 205-220.

O’Connor P., Höpken W. \& Gretzel U. (2008). Information and communication technologies 2008. Proceeding of the international conference in Innsbruck, Austria, 2008. Springer Wien NewYork.

O'Reilly T. (2005). What is web 2.0. Design patterns and business models for the next generation of software, Retrieved from: http://oreilly.com/web2/archive/what-is-web-20.html.

OTTI (2010). 2009 U.S. Resident Travel to Europe. Retrieved from: http://tinet.ita.doc.gov/outreachpages/outbound.general information.outbound_overview.html.

OTTI (2010). 2009 U.S. United States Resident Travel Abroad. Retrieved from: http://tinet.ita.doc.gov/outreachpages/out bound.general_information.outbound_overview.html.

OTTI (2010). Profile of U.S. Resident Travelers Visiting Overseas destination: 2009 Outbound. Retrieved from: http://tinet.ita.doc.gov/outreachpages/outbound.general_infor mation.outbound_overview.html.

Pan B. \& Fesenmaier D. R. (2006). Online information search. Vacation planning process. Annals of Tourism Research 33 (3), 809-832.

Pan B., Xiang Z., Law R. \& Fesenmaier D.R. (2011). The dynamics of search engine marketing for tourist destinations. Journal of Travel Research, 50 (4), 365-377.

PhoCusWright's Online traffic and conversion. Report PhoCusWright, September 2009.

PhoCusWright's Research Highlights: PhoCusWright's U.S. Online Travel Overview Tenth Edition, December 2010.

PhoCusWright's Understanding online travel agencies' Cost Drivers and Ways to Optimise Business in Europe, July 2010

Poon A. (1993). Tourism, technology and competitive strategies. CAB International: Wallingford.

Poon A., (1988). Tourism and information technologies. Annals of Tourism Research 15 (4), 531-549.

Rachman Z. \& Richins H. (1997). The status of New Zeland tour operator web sites. Journal of Tourism Studies, 8 (2), 62-77.

Rifkin J. (2000). L'era dell'accesso. La rivoluzione della new economy. Mondadori. Milano.

Ryan C. \& Rao U. (2008). Holiday users of the internet - ease of use, functionality and novelty. International Journal of Tourism Research 10 (4), 329-339.

Shaw A. \& Williams A. M. (1994). Critical issues in tourism: a geographical perspective. Blackwell, Oxford.

Smith C. \& Jenner P.(1998). Tourism and the internet. Travel and Tourism Analyst, 1, 62-81.

Stamboulis Y. \& Skayannis P. (2003). Innovation strategies and technology for experience-based tourism. Tourism Management, 24, 35-43.

Toffler A. (1981). The third wave. Bantam Books, New York.

Trunfio M., Nigro C. \& Petruzzellis L., (2006). Tour Operators and alternatives tourism in Italy: exploiting niche markets to increase international competitiveness. International Journal of Contemporary Hospitality Management 18 (5), 426-438.

Tussyadiah I. P. \& Fesenmaier D. R. (2009). Mediating tourist experiences. Access to place via shared videos. Annals of Tourism Research 36 (1), 24-40.

U.S. Travel Association \& NLTeC (2009). Travelers' use of the internet. 2009 Edition published by U.S. Travel Association.

Vinod, B. (2011). The future of online travel. Journal of Revenue and Pricing Management,10,56-61. 
Wang Y. \& Fesenmaier D. (2002). Defining the virtual tourist community: implications for tourism marketing. Tourism Management, 30, 51-62.

Wan C. (2002). The web sites of international tourist hotels and tour wholesaler in Taiwan. Tourism Management, 23 (2), 155-160.

Weber K. \& Roehl W. S. (1999). Profiling people searching for and purchasing travel products on the World Wide Web. Journal of Travel Research, 25 (3), 551-578.

Woodside A. G. \& Lysonsky S. (1989). A general model of travel destination choice. Journal of Travel Research 27, 8-14.

Xiang Z. \& Pan B. (2011). Travel queries on cities in the United States: Implications for search engine marketing for tourist destinations. Tourism Management, 32, (1), 88-97.
Xiang Z. \& Gretzel U. (2010). Role of social media in online travel information search. Tourism Management, 31 (2), 179-188.

Xiang Z., Wöber K. \& Fesenmaier D.R. (2008). Representation of the on-line tourism domain in search engines. Journal of Travel Research, 47 (2), 137-150.

Yale P. (1995). The business of tour operations. Longman: Essex

Zhang Z. (2004). Organizing customers: Japanese travel agencies marketing on the Internet. European Journal of Marketing, $38(9 / 10), 1294-1303$.

Zeher A., Crotts J. C. \& Magnini V. P., (2011). The perceived usefulness of blog posting: an extension of the expectancydisconfirmation paradigm. Tourism Management 32 (1),106-113. 